\title{
Exergy Analysis of Food Drying Processes
}

\author{
Neslihan Colak, Mustafa T. Balta, Filiz Içier, Ebru Kuzgunkaya, Arif Hepbasli
} and Zafer Erbay

\subsection{Introduction}

It is well known that micro-level system parameters may have some great impact on macro-level energy aspects, the environment, and sustainability. Of course, if one wants to approach these thermodynamically, there are two ways: energy analysis through the first law of thermodynamics and exergy analysis through the second law of thermodynamics. Exergy analysis is an essential tool to expose the impacts of a power generating device on exergy-based sustainability; sustainability is necessary to overcome current ecological, economic, and developmental problems (Dincer and Rosen, 2005). In this regard, some new exergy-based sustainability parameters for a PEM fuel cell have been developed and studied parametrically to investigate how they will help measure the level of environmental impact and sustainable development (Midilli and Dincer, 2009). These types of parameters may also be applied to other energy-related systems.

Drying has been used worldwide for centuries to preserve different food and agricultural products. Nowadays, the drying process is one of the major procedures of food preservation. The basic target of food dehydration is to remove water to a final concentration, which assures microbial spoilage of the product and minimizes chemical and physical changes of the food during storage (Crapiste and Rotstein, 1997). Drying is an energy-intensive operation consuming 9-25\% of national energy in the developed countries (Mujumdar, 1995). In many practical applications, drying is a process that requires high-energy input because of the high latent heat of water evaporation and relatively low-energy efficiency of industrial dryers.

For development of sustainable energy, three important technological changes have been required: energy economies on the demand side, efficiency improvements in the energy production, and renewing of fossil fuels by various sources of renewable energy. 
Heat pumps (HPs) are devices for raising the temperature of low grade heat energy to a more useful level using a relatively small amount of high grade energy. Using HPs in convective hot air dryers has been recognized as an ideal area for HP applications (Schmidt et al., 1998). The energy efficiencies of conventional dryers are generally very low, a value of $35 \%$ being representative of the upper performance range (Lawton, 1978). Strommen et al. (2002) found that HPDs consume between $60 \%$ and $80 \%$ less energy than conventional dryers operating at the same temperature. This makes such dryers a feasible option for users who are not satisfied with the comparatively high energy consumption of directly heated dryers (Schmidt et al., 1998).

The most effective way to reduce energy demand is to use energy more efficiently. In this regard, exergy analysis, based on the second law of thermodynamics, successfully identifies the magnitudes and locations of energy degradations, inefficient uses of natural resources, and the pollution of the environment by means of waste energy (Kotas, 1985). If the less energy goes into production and marketing of foods, the less global warming pollution is created.

Exergy analysis evaluates the available energy at different points in a system. In the design of a system, the exergy method can be used to extract useful information to aid the task of choosing the most appropriate component design and operation procedure. This information is much more effective in determining the plant and operation costs, energy conservation, fuel versatility, and pollution levels. Bejan (1982) pointed out that the minimization of lost work in the system would provide the most efficient system. Moreover, Bejan (1988) and Szargut et al. (1988) emphasized that the effect of operating conditions on the system efficiency was much stronger for lost-work analysis than it is for the heat balance analysis. This explanation is required to determine the inefficient processes, equipment, or operating procedures during drying. For evaluating the performance of food drying systems, energy analysis method has been widely used, while the studies on exergy analysis are relatively few in number.

Fresh fruits and vegetables have both important nutritional and economic value. Recently, the market demand for naturally processed fruits and vegetables has undergone an important rise because of increasing health-conscious consumers. In vegetables broccoli is described as a vegetable with a high nutritional value due to its important content of vitamins, antioxidants, and anti-carcinogenic compounds (Nestle, 1998). Broccoli dehydration has not been investigated to a great extent and a few data are available in the literature (Bon et al., 1997; Simal et al., 1998; Mulet et al., 1999; Sanjuan et al., 2001; Mrkic et al., 2007). Annual broccoli production of Turkey increased $90.3 \%$ from 2005 to 2006 and reached 16,178 tonnes (Turkish Statistical Institute, 2006). It is estimated that production of this vegetable will rise gradually in Turkey and the world.

In this study, exergy analysis of food drying processes is presented and applied to broccoli drying process in a heat pump-driven conveyor dryer as a case study. Broccoli florets were dried at $45^{\circ} \mathrm{C}, 50^{\circ} \mathrm{C}$, or $55^{\circ} \mathrm{C}$ drying air temperatures and $0.5 \mathrm{~m} / \mathrm{s}$, $1 \mathrm{~m} / \mathrm{s}$, or $1.5 \mathrm{~m} / \mathrm{s}$, drying air velocities. Effects of temperatures and mass flow rates on the exergy losses, exergy efficiencies, and improvement potentials of the drying process were investigated. 


\subsection{Case Study: Broccoli Drying}

Fresh broccoli (Brassica oleracea) was purchased from a local market in Izmir, Turkey. It was processed within $24 \mathrm{~h}$. Broccoli samples were washed with water, and then the excess water on the surface of broccoli was removed with filter paper. Afterward, florets of broccoli were separated.

Broccoli florets were dried in a heat pump conveyor dryer designed and constructed in the Department of Mechanical Engineering, Faculty of Engineering, Ege University, Izmir, Turkey, shown schematically in Fig. 15.1. Drying system consists of two main parts: (i) heat pump and (ii) drying chamber. The air was heated by heat pump system that included a scroll compressor, two condenser (an internal and an external ones), expansion valve, evaporator, and a heat recovery unit and air temperature was controlled by a control unit. R407C was used as refrigerant in heat pump system. The drying air velocity was regulated by a fan and fan speed control unit and drying air was recycled. Drying compartment dimensions were $3 \mathrm{~m} \times 1 \mathrm{~m} \times 1 \mathrm{~m}$ and drying material was moved by a conveyor band system worked by a motor.

\subsubsection{Drying procedure and measurements}

After the dryer reached steady-state conditions, broccoli florets were spread onto a couple of trays as thin layer settled onto the conveyor band. Drying experiments were carried out at the drying air temperatures of $45^{\circ} \mathrm{C}, 50^{\circ} \mathrm{C}$, or $55^{\circ} \mathrm{C}$, and drying air velocities of $0.5 \mathrm{~m} / \mathrm{s}, 1.0 \mathrm{~m} / \mathrm{s}$, or $1.5 \mathrm{~m} / \mathrm{s}$, respectively.

Moisture loss was recorded at $30 \mathrm{~min}$ intervals during drying process for determination of drying curves. The sample moisture content was determined with vacuum-oven method (AOAC, 1990). The initial moisture content of the broccoli floret samples was determined $86.44 \%$ on a wet basis. The composition of broccoli florets used in this study is given in Table 15.1 (Anon., 2008).

Table 15.1. Composition of broccoli florets (Anon, 2008).

\begin{tabular}{|c|c|}
\hline Component & Amount (\%) \\
\hline Water & 86.44 \\
\hline Protein & 2.91 \\
\hline Oil & 0.38 \\
\hline Carbohydrate & 6.69 \\
\hline Fiber & 2.68 \\
\hline Ash & 0.90 \\
\hline
\end{tabular}

Humidities, temperatures, and velocities were measured in drying chamber with robust humidity probes (Testo, 0636.2140, Freiburg, Germany), vane/temperature probes (Testo, 0635.9540, Freiburg, Germany), professional telescopic handle for plug-in vane probes (Testo, 0430.0941, Freiburg, Germany), respectively. Measurements of drying air temperature, velocity, and relative humidity were recorded at inlet and outlet holes at every $10 \mathrm{~min}$. The surface temperature of drying material was measured by an infrared thermometer (Testo 525-T2, infrared 
thermometer with laser sighting). The temperature of the drying chamber walls was measured with a digital multimeter (METEX ME-32) during drying process. A digital balance (Scaltec SBA 61, Goettingen, Germany) was used to measure the weight loss of sample during drying experiments. The ambient temperature and the relative humidity were also measured and recorded. Pressures and temperatures of the refrigerant were measured with pressure probes (Testo, low/high-pressure probes, 0638.01941) and surface temperature probes (Testo, temperature probes, 0628.0019), respectively. All measured values were observed and recorded with a multi-function instrument (Testo 350-XL/454, control unit, Freiburg, Germany) and loggers. The schematic diagram of the drying process and measurements were shown in Fig. 15.1.

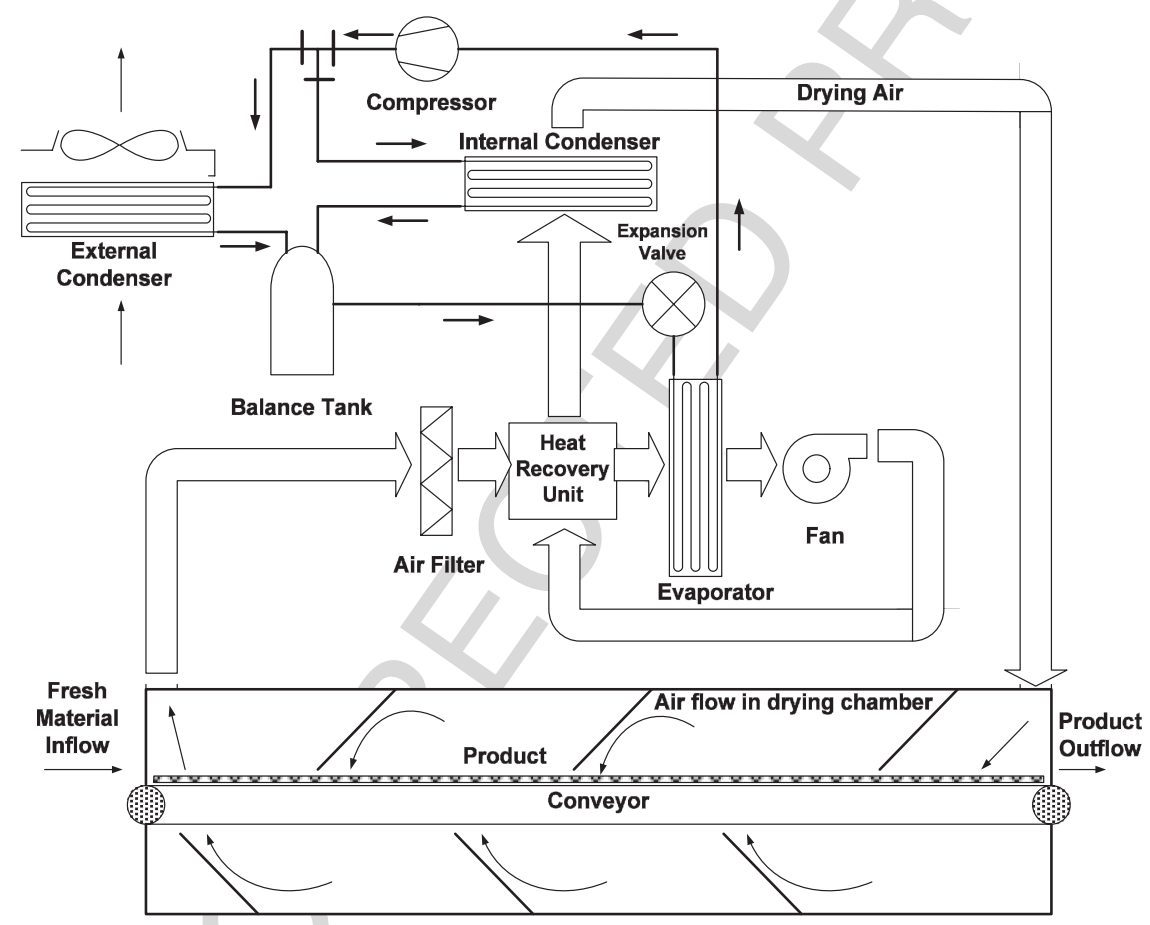

Fig. 15.1 Schematic illustration of heat pump conveyor dryer system.

15.2.2. Determination of thermal properties of food and drying air

Specific heat of food materials has been determined experimentally by several methods, including the method of mixtures, method of guard plate, and using a differential scanning calorimeter (Choi and Okos, 1986; Singh, 1992). Choi and Okos (1986) have suggested the following model for the specific heat for foods:

$$
C=\sum C_{i} X_{i}
$$

with the specific heat of pure components given as 


$$
\begin{aligned}
& C=C_{w} X_{w}+C_{p} X_{p}+C_{f} X_{f}+C_{c} X_{c}+C_{f i} X_{f i}+C_{a s h} X_{a s h} \\
& C_{w}=4.1762-9.0864 \times 10^{-5} T+5.4731 \times 10^{-6} T^{2} \text { for water } \\
& C_{p}=2.0082+1.2089 \times 10^{-3} T-1.3129 \times 10^{-6} T^{2} \text { for protein } \\
& C_{f}=1.9842+1.4733 \times 10^{-3} T-4.8008 \times 10^{-6} T^{2} \text { for fat } \\
& C_{c}=1.5488+1.9625 \times 10^{-3} T-5.9399 \times 10^{-6} T^{2} \text { for carbohydrate } \\
& C_{f i}=1.8459+1.8306 \times 10^{-3} T-4.6509 \times 10^{-6} T^{2} \text { for fiber } \\
& C_{a s h}=1.0926+1.8896 \times 10^{-3} T-3.6817 \times 10^{-6} T^{2} \text { for ash }
\end{aligned}
$$

where $T$ is the temperature of food; the units of the specific heats and temperatures are $\mathrm{kJ} / \mathrm{kg}{ }^{\circ} \mathrm{C}$ and ${ }^{\circ} \mathrm{C}$, respectively. The composition of the broccoli used in this study was given in Table 15.1.

The above theoretical models are based on proportions by compositions. There is deviation between the experimental values and the above model due to (1) specific heat of the component phases varied with the source or origin, (2) bound water or unfrozen water has a different specific heat than bulk water, (3) excess specific heat due to the interaction of the component phases (Rahman, 1995).

The enthalpy of drying air can be written as

$$
h_{d a}=c_{P d a} T+\omega h_{s a t @ T}
$$

where $c_{P d a}$ defines the specific heat of drying air, $T$ the drying air temperature, $\omega$ the specific humidity, and $h_{\text {sat@ } T}$ is the enthalpy of the saturated vapor. 1995)

$$
h=\sum h_{i} X_{i}=\sum \int_{T_{1}}^{T_{2}} C_{i} X_{i} \mathrm{~d} T
$$

where $h$ is the enthalpy of the individual food components and $X_{i}$ is the mass fraction of food components.

The specific entropies of broccoli are given as (Syahrul et al., 2002)

$$
\begin{aligned}
& s_{m 1}-S_{m 0}=C_{m 1} \ln \left(T_{m 1} / T_{m 0}\right) \\
& S_{m 2}-s_{m 0}=C_{m 2} \ln \left(T_{m 2} / T_{m 0}\right)
\end{aligned}
$$

where $T_{m 0}$ was the reference temperature, which was taken to be $23^{\circ} \mathrm{C}$ in this study 
and $T_{m 2}$ was the temperature of food item in ${ }^{\circ} \mathrm{C}$.

To evaluate the entropy of moist air, the contribution of each component in the mixture is determined at the mixture temperature and the partial pressure of the component (Syahrul et al, 2002):

$$
s_{d a}=s_{a}-R_{a} \ln \frac{P_{a}}{P_{0}}+w\left(s_{v}-R_{v} \ln \frac{P_{v}}{P_{0}}\right)
$$

\subsubsection{Energy and exergy balance equations}

For a general steady-state, steady-flow process, the four balance equations are applied to find the work and heat interactions, the rate of exergy decrease, the rate of irreversibility, the energy and exergy efficiencies (Kotas, 1985).

The general energy balance can be expressed as

$$
\sum \dot{E}_{\text {in }}=\sum \dot{E}_{\text {out }} \quad \text { or } \quad \dot{Q}+\sum \dot{m}_{\text {in }} \dot{h}_{\text {in }}=\dot{W}+\sum \dot{m}_{\text {out }} \dot{h}_{\text {out }}
$$

where $\dot{m}$ is the mass flow rate and the subscript in stands for inlet and out for outlet, $\dot{E}_{\text {in }}$ is the rate of net energy transfer in, $\dot{E}_{\text {out }}$ is the rate of net energy transfer out by heat, work, and mass, $\dot{Q}=\dot{Q}_{\text {net, in }}=\dot{Q}_{\text {in }}-\dot{Q}_{\text {out }}$ is the rate of net heat input, $\dot{W}=\dot{W}_{\text {net,out }}=\dot{W}_{\text {out }}-\dot{W}_{\text {in }}$ is the rate of net work output, and $h$ is the enthalpy per unit mass.

The general exergy balance can be expressed in the rate form as

$$
\begin{aligned}
& \sum \dot{E} x_{\text {in }}-\sum \dot{E} x_{\text {out }}=\sum \dot{E} x_{\text {dest }} \text { or } \\
& \sum\left(1-\frac{T_{0}}{T_{k}}\right) \dot{Q}_{k}-\dot{W}+\sum \dot{m}_{\text {in }} \psi-\sum \dot{m}_{\text {out }} \psi=\dot{E} x_{d e s t} \\
& \psi=\left(h-h_{0}\right)-T_{0}\left(s-s_{0}\right)
\end{aligned}
$$

where $\dot{Q}_{k}$ is the heat transfer rate through the boundary at temperature $T_{k}$ at location $k, \dot{W}$ is the work rate, $\psi$ is the flow exergy, $s$ is the specific entropy, and the subscript zero indicates properties at the dead state of $P_{0}$ and $T_{0}$.

The exergy destroyed or the irreversibility may be expressed as follows:

$$
\dot{I}=\dot{E} x_{\text {dest }}=T_{0} \dot{S}_{g e n}
$$

where $\dot{S}_{g e n}$ is the rate of entropy.

Van Gool (1997) has also proposed that maximum improvement in the exergy efficiency for a process or system is obviously achieved when the exergy loss 
or irreversibility $\left(\dot{E} x_{\text {in }}-\dot{E} x_{\text {out }}\right)$ is minimized. Consequently, he suggested that it is useful to employ the concept of an exergetic 'improvement potential rate' when analyzing different processes or sectors of the economy. This improvement potential in the rate form, denoted $I \dot{P}$, is given as (Hammond and Stapleton, 2001)

$$
I \dot{P}=(1-\eta)\left(\dot{E} x_{\text {in }}-\dot{E} x_{\text {out }}\right)
$$

Total exergy inflow, outflow, and losses of the tray and the drying chamber were estimated based on the exergy analysis, which determined the exergy values at steady-state points and the reason of exergy variation for the process.

Exergy analysis was performed for conveyor dryer framed with cutting lines in Fig. 15.1. Exergy balance equation for the conveyor dryer was

$$
\dot{E} x_{m 2}-\dot{E} x_{m 1}=\dot{E} x_{d a 1}-\dot{E} x_{d a 2}+\dot{E} x_{e v a p}-\dot{E} x_{l o s s}-\dot{E} x_{d e s t}
$$

where $\dot{E} x_{m}$ was the exergy transfer rate of the material, $\dot{E} x_{d a}$ was the exergy transfer rate of the drying air, $\dot{E} x_{\text {evap }}$ was the exergy evaporation rate of the dryer, $\dot{E} x_{\text {loss }}$ was the rate of exergy loss in the surrounding, and $\dot{E} x_{D}$ was the rate of exergy destruction in the dryer.

The specific exergies at inlets $\left(\psi_{m 1}\right)$ and outlets $\left(\psi_{m 2}\right)$ of the material were given as follows (Syahrul et al., 2002):

$$
\begin{aligned}
& \psi_{m 1}=\left(h_{m 1}-h_{m 0}\right)-T_{0}\left(s_{m 1}-s_{m 0}\right) \\
& \psi_{m 2}=\left(h_{m 2}-h_{m 0}\right)-T_{0}\left(s_{m 2}-s_{m 0}\right)
\end{aligned}
$$

Specific exergies with a stream of drying air entering and leaving the dryer were as follows (Syahrul et al., 2002):

$$
\begin{aligned}
& \psi_{d a 1}=\left(h_{1}-h_{0}\right)-T_{0}\left(s_{1}-s_{0}\right) \\
& \psi_{d a 2}=\left(h_{2}-h_{0}\right)-T_{0}\left(s_{2}-s_{0}\right)
\end{aligned}
$$

where $\psi_{d a 1}$ and $\psi_{d a 2}$ were the specific exergy transfers at inlets and outlets, respectively; $h_{0}, s_{0}$ denoted the specific enthalpy and specific entropy at the temperature of dead state $\left(T_{0}\right)$, respectively; $h_{1}$ and $s_{1}$ denoted the specific enthalpy and the specific entropy at the temperature of drying air entering the dryer $\left(T_{d a 1}\right)$, respectively; $h_{2}$ and $s_{2}$ denoted the specific enthalpy and the specific entropy of drying air at the temperature of the drying air exiting, respectively. The potential and kinetic exergies were negligible.

The heat transfer rate due to phase change was (Syahrul et al., 2002) 


$$
\dot{Q}_{\text {evap }}=\dot{m}_{w} \cdot h_{f g}
$$

The rate of exergy transfer due to evaporation of the dryer was (Syahrul et al., 2002)

$$
\dot{E} x_{\text {evap }}=\left[1-\frac{T_{0}}{T_{m 2}}\right] \dot{Q}_{\text {evap }}
$$

Heat transfer rate to the environment was (Syahrul et al., 2002)

$$
\dot{Q}_{\text {loss }}=\dot{Q}_{\text {evap }}-\dot{m}_{1}\left(h_{m 2}-h_{m 1}\right)+\dot{m}_{d a}\left(h_{d a 1}-h_{d a 2}\right)
$$

The following equation was used to calculate the rate of exergy loss to the surrounding, where $T_{b}$ is the boundary temperature (Syahrul et al., 2002):

$$
\dot{E} x_{\text {loss }}=\left(1-\frac{T_{0}}{T_{b}}\right) \dot{Q}_{\text {loss }}
$$

The exergy efficiency of the dryer can be defined as the ratio of the product exergy to exergy inflow for the chamber. Thus, the general form of exergy efficiency was written as

$\eta_{e x}=1-\frac{\dot{E} x_{\text {loss }}}{\dot{E} x_{\text {in }}}$

\subsubsection{Results for the case study}

In this section, effects of the drying air temperature and the mass flow rate of drying air on the system performance were discussed. Specific heats, enthalpies, and entropies of the broccoli florets were calculated from Eqs. (15.2), (15.10), and (15.11-15.12), respectively. The properties of the inlet and outlet air were calculated from the computer aided thermodynamic tables. The reference (dead state) temperature for exergy analyses was taken to be $23^{\circ} \mathrm{C}$. Exergy analyses of singlelayer drying process of broccoli florets in a heat pump conveyor dryer were performed by using the data obtained from the experiments (Table 15.2).

The variations of exergy efficiency and improvement potentials with drying air temperatures at various drying air velocities were illustrated in Figs. 15.2 and 15.3, respectively. As can be seen in Fig. 15.2, exergy efficiency of the drying chamber decreased as the drying air temperature increased at all velocities. When the air temperature was $45^{\circ} \mathrm{C}$ and velocity was $1.5 \mathrm{~m} / \mathrm{s}$, exergy efficiency of the system was determined to be $76.58 \%$. It was obvious from Fig. 15.3 that the improvement potential rate of the drying chamber at $55^{\circ} \mathrm{C}$ and $0.5 \mathrm{~m} / \mathrm{s}$ was found to be $13.86 \mathrm{~kW}$ as minimum value. Also, improvement potential value for $1.5 \mathrm{~m} / \mathrm{s}$ was lower than the other velocities at $45^{\circ} \mathrm{C}$. 
Figures 15.4 and 15.5 show the exergy loss and destructions changing with drying air temperatures at various drying air velocities.

Table 15.2. Data from the experiments and calculations made.

\begin{tabular}{|l|l|l|l|l|l|l|l|l|l|}
\hline $\begin{array}{l}T_{\text {dal }} \\
\left({ }^{\circ} \mathrm{C}\right)\end{array}$ & $\begin{array}{l}V \\
(\mathrm{~m} / \mathrm{s})\end{array}$ & $\begin{array}{l}\omega_{1} \\
(\mathrm{~g} / \mathrm{g})\end{array}$ & $\begin{array}{l}\omega_{2} \\
(\mathrm{~g} / \mathrm{g})\end{array}$ & $\begin{array}{c}h_{1} \\
(\mathrm{~kJ} / \mathrm{kg})\end{array}$ & $\begin{array}{c}H_{2} \\
(\mathrm{~kJ} / \mathrm{kg})\end{array}$ & $\begin{array}{l}S_{1} \\
(\mathrm{~kW} / \\
\left.{ }^{\circ} \mathrm{C}\right)\end{array}$ & $\begin{array}{l}S_{2} \\
(\mathrm{~kW} /\end{array}$ & $\begin{array}{l}C_{m 1} \\
(\mathrm{~kJ} / \mathrm{kg} \\
\left.{ }^{\circ} \mathrm{C}\right)\end{array}$ & $\begin{array}{l}C_{m 2} \\
(\mathrm{~kJ} / \mathrm{kg}\end{array}$ \\
\hline \multirow{2}{*}{45} & 0.5 & 0.0068 & 0.0073 & 337.278 & 336.041 & 6.914 & 6.919 & 3.845 & 2.096 \\
& 1.0 & 0.0075 & 0.0082 & 339.087 & 338.364 & 6.919 & 6.926 & 3.845 & 2.096 \\
& 1.5 & 0.0068 & 0.0073 & 336.771 & 335.634 & 6.915 & 6.919 & 3.845 & 2.096 \\
\hline \multirow{3}{*}{50} & 0.5 & 0.0076 & 0.0078 & 343.599 & 339.455 & 6.919 & 6.922 & 3.845 & 2.101 \\
& 1.0 & 0.0082 & 0.0086 & 346.071 & 343.248 & 6.923 & 6.927 & 3.845 & 2.101 \\
& 1.5 & 0.0084 & 0.0089 & 345.673 & 343.724 & 6.926 & 6.930 & 3.845 & 2.101 \\
\hline \multirow{3}{*}{55} & 0.5 & 0.0090 & 0.0097 & 351.191 & 348.642 & 6,929 & 6.935 & 3.845 & 2.106 \\
& 1.0 & 0.0094 & 0.0097 & 351.731 & 348.533 & 6.931 & 6.935 & 3.845 & 2.106 \\
& 1.5 & 0.0101 & 0.0109 & 355.480 & 353.985 & 6.936 & 6.943 & 3.845 & 2.106 \\
\hline
\end{tabular}

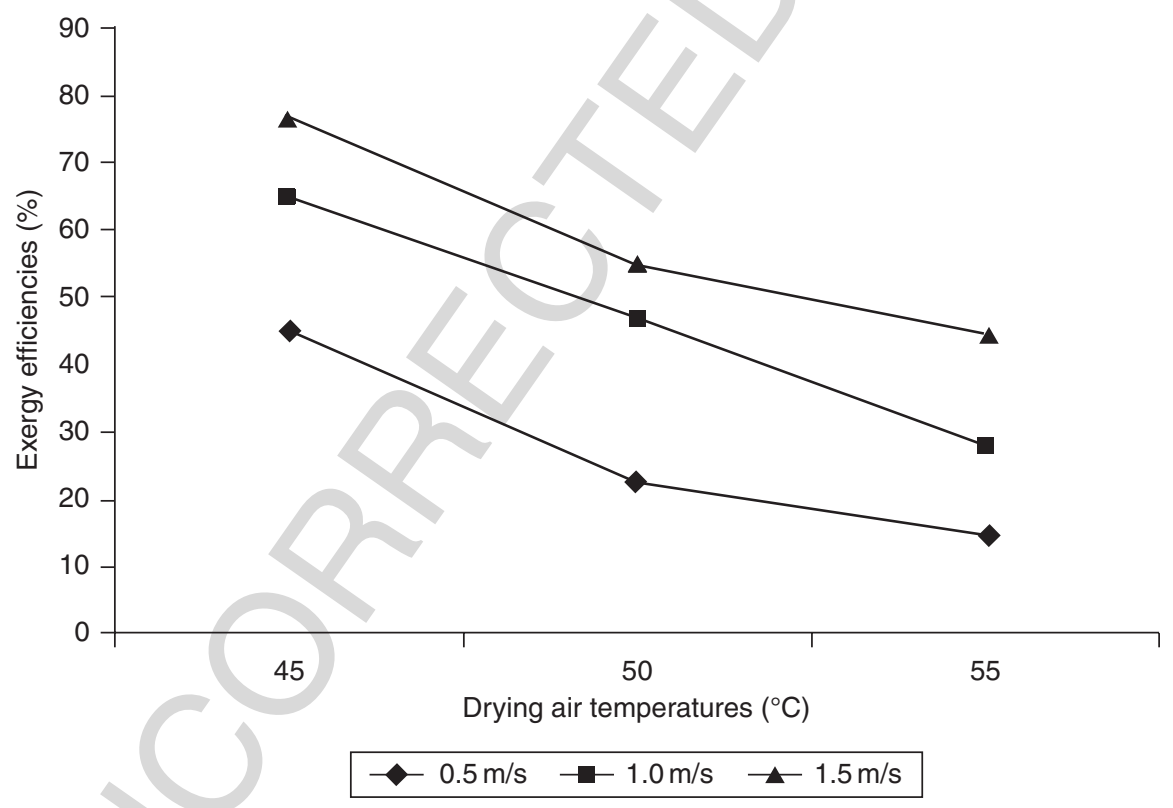

Fig. 15.2 The variations of exergy efficiencies with drying air temperatures at different drying air velocities. 


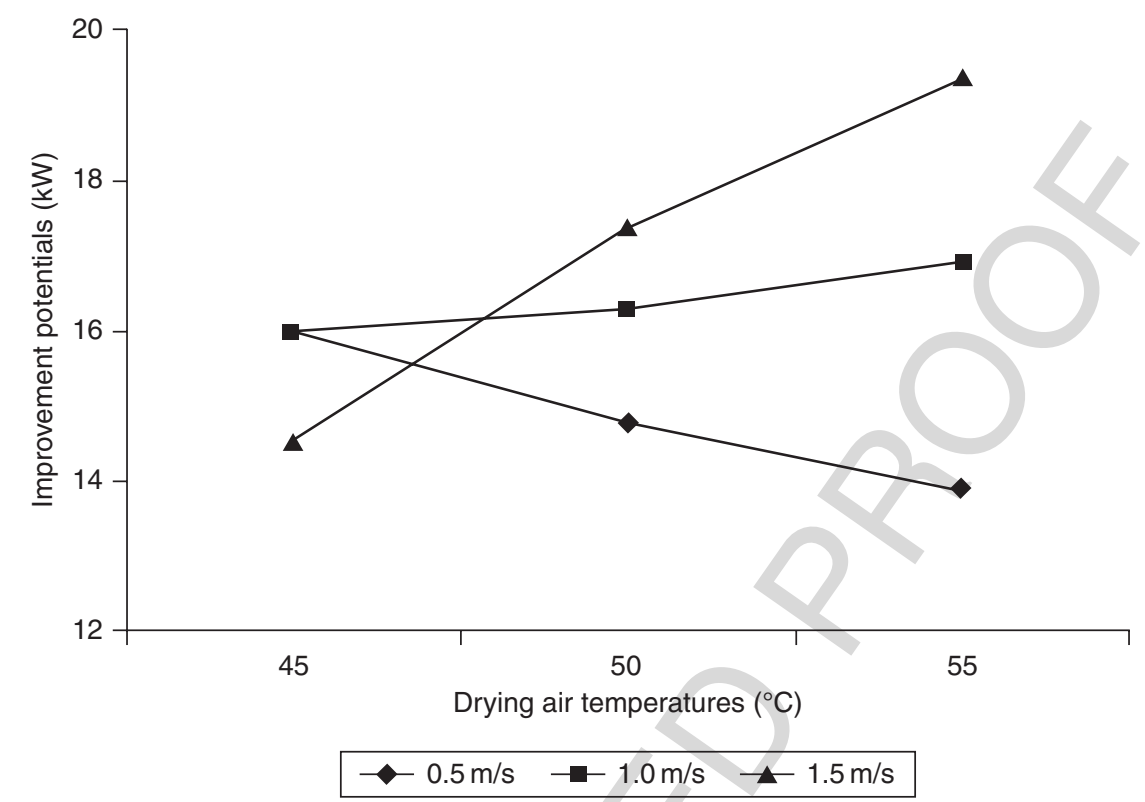

Fig. 15.3 The variations of improvement potentials with drying air temperatures at different drying air velocities.

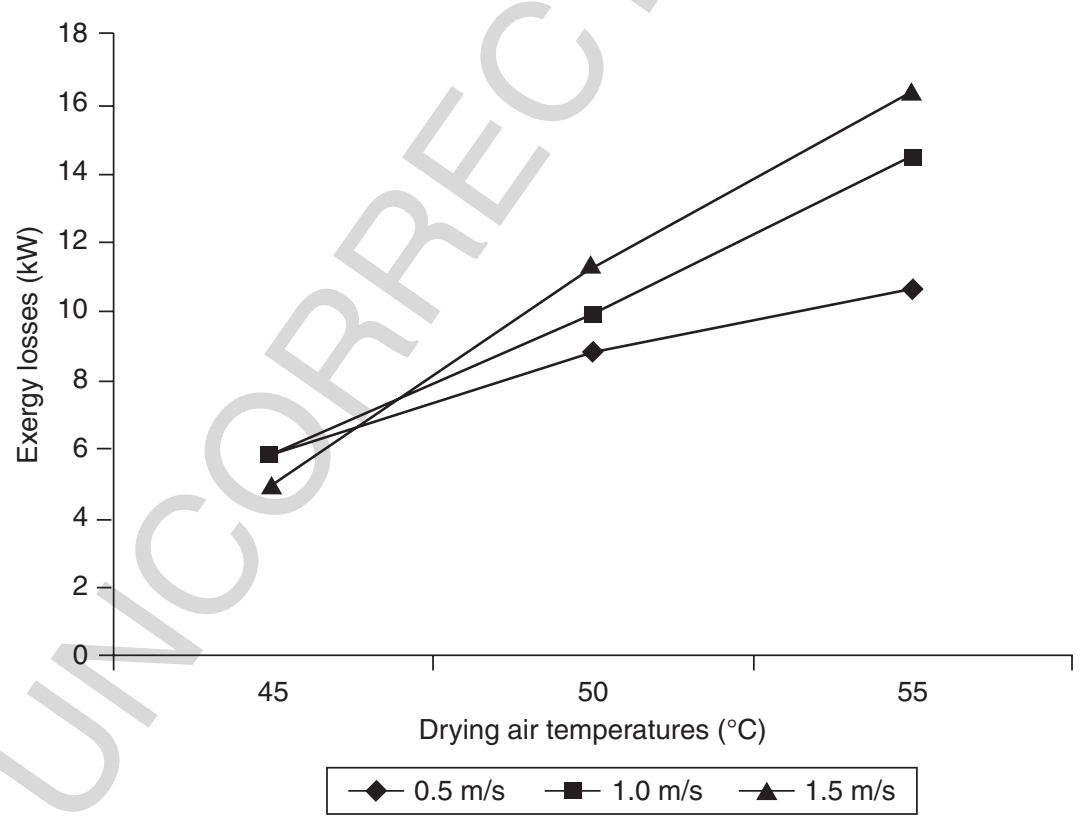

Fig. 15.4 Variations of exergy losses with drying air temperatures at different air velocities. 


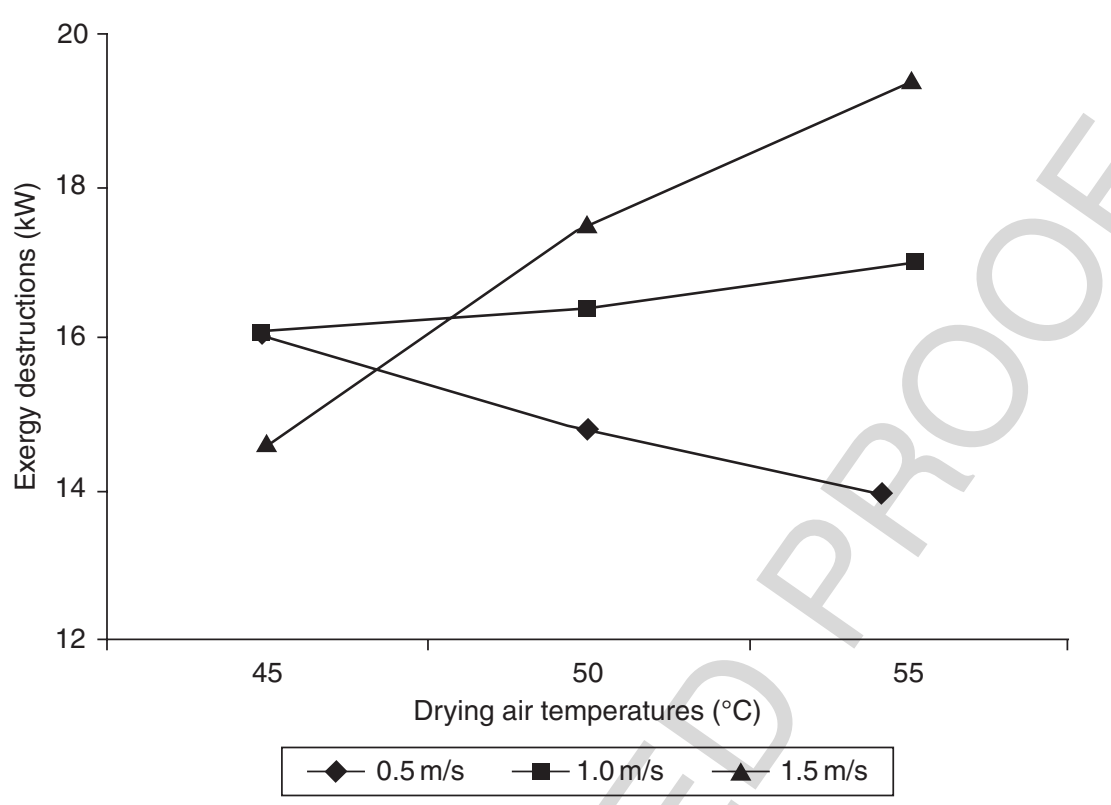

Fig. 15.5 Variations of exergy destructions with drying air temperatures at different air velocities.

\subsection{Conclusions}

For better environment and sustainability it is really important to improve food drying systems and processes and their efficiencies. This chapter presents an exergy analysis of drying process of broccoli florets in a heat pump conveyor dryer. Some concluding remarks are drawn from this study as follows:

- Exergy efficiency and the improvement potential rate of the drying chamber vary from $14.79 \%$ to $76.58 \%$ and $13.86 \mathrm{~kW}$ to $19.29 \mathrm{~kW}$, respectively.

- Exergy loss of this system increases with raising the temperatures of drying air, when exergy destruction was decreased at $0.5 \mathrm{~m} / \mathrm{s}$ drying air velocity.

- The maximum exergy efficiency value becomes $76.58 \%$ at a drying air temperature of $45^{\circ} \mathrm{C}$ and a velocity of $1.5 \mathrm{~m} / \mathrm{s}$.

\section{Acknowledgments}

The authors are grateful for the financial support provided for the project entitled "Design, test and performance evaluation of a gas engine driven solar assisted band conveyor heat pump drying system" under Project No. 106M482 by The Scientific and Technological Research Council of Turkey (TUBITAK). 


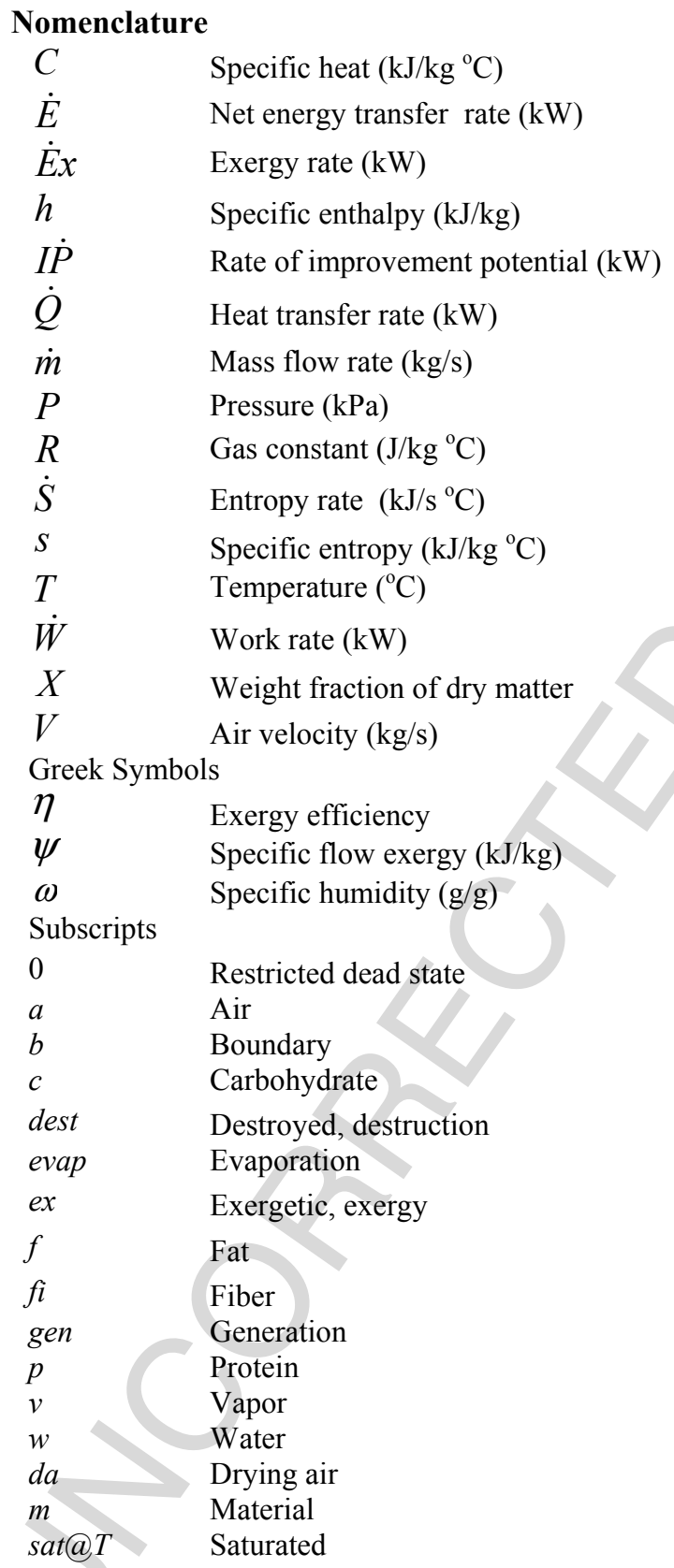




\section{References}

Anon (2008) www.nal.usda.gov/fnic/foodcomp. Accessed on May 20, 2008.

AOAC (1990) Official Method of Analysis. Association of Official Analytical Chemist, Washington, DC, (No: 934.06).

Bejan, A. (1982) Entropy Generation Through Heat and Fluid Flow, Wiley, New York, NY.

Bejan, A. (1988) Advanced Engineering Thermodynamics, Wiley, NewYork, NY.

Bon, J, Simal, S, Rossello, C, Mulet, A (1997) Drying characteristics of hemispherical solids. Journal of Food Engineering 34: 109-122.

Choi, Y, Okos, MR (1986) Effects of temperature and composition on the thermal properties of foods. Food Engineering and Process Applications, Vol. 1, Transport Phenomenon. Edited by Maguer, L., Jelen, P. Elsevier, New York, 93-101.

Crapiste, GH, Rotstein, E (1997) Design and performance evaluation of dryers. Handbook of Food Engineering Practice. Edited by K.J. Valentas, E. Rotstein and R.P. Singh, CRC Press, New York, 125-166.

Dincer, I, Rosen, MA (2005) Thermodynamic aspects of renewables and sustainable development. Renewable and Sustainable Energy Reviews 9(2): 169-189.

Hammond, GP, Stapleton, AJ (2001) Exergy analysis of the United Kingdom energy system. Proceedings of the Institution of Mechanical Enginers 215(2): 141-162.

Kotas, TJ (1985) The Exergy Method of Thermal Plant Analysis. Essex, Brendon Ltd.

Lawton, J (1978) Drying: the role of heat pumps and electromagnetic fields. Physics Technology 9: 214-220.

Midilli, A, Dincer, I (2009) Development of some exergetic parameters for PEM fuel cells for measuring environmental impact and sustainability. In Press: International Journal of Hydrogen Energy. doi:10.1016/j.ijhydene.2009.02.066.

Mrkic, V, Ukrainczyk, M, Tripalo, B (2007) Applicability of moisture transfer Bi-Di correlation for convective drying of broccoli. Journal of Food Engineering 79: 640-646.

Mujumdar, AS (1995) Handbook of Industrial Drying, Vol. 2, Marcel Dekker Inc., New York. Mulet, A, Sanju'an, N, Bon, J, Simal, S (1999) Drying model for highly porous hemispherical bodies. European Food Research and Technology 210: 80-83.

Nestle, M (1998) Broccoli sprout in cancer prevention. Nutrition Reviews 56: 127-130.

Rahman, S (1995) Food Properties Handbook. CRC Press, US, 225-271.

Sanjuan, N, Clemente, G, Bon, J, Mulet, A (2001) The effect of blanching on the quality of dehydrated broccoli florets. European Food Research Technology 213: 474-479.

Schmidt, EL, Klocker, K, Flacke, N, Steimle, F (1998) Applying the transcritical $\mathrm{CO}_{2}$ process to a drying heat pump. International Journal of Refrigeration 21(3): 202-211.

Simal, S, Rossellb, C, Berna, A, Mulet, A (1998) Drying of shrinking cylinder-shaped bodies. Journal of Food Engineering 37: 423-435.

Singh, RP (1992) Handbook of Food Engineering, Edited by Heldman DR, Lund DB. Marcel Dekker Inc: New York; 247-276.

Strommen, I, Eikevik, TM, Alves-Filho, O, Syverud, K, Jonassen, O (2002) Low temperature drying with heat pumps new generations of high quality dried products. 13th International Drying Symposium.

Syahrul, S, Hamdullahpur, F, Dincer, I (2002) Exergy analysis of fluidised bed drying of moist particles. Exergy, an International Journal 2: 87-98.

Szargut, J, Morris, DR, Stewart, FR (1988) Exergy Analysis of Thermal, Chemical and Metallurgical Processes, Taylor \& Francis, New York.

Van Gool, W (1997) Energy policy: fairly tales and factualities. In: Innovation and Technology-Strategies and Policies, ODD. Edited by Soares, A. Martins da Cruz, G. Costa Pereira, IMRT. Soares and AJPS. Kluwer, Dordrecht, 93-105. 